\title{
Students' Acceptance of Teaching Interaction through the Diversity of Media in M-Learning
}

\section{Mohd Hasril Amiruddin ${ }^{1}$, Sri Sumarwati ${ }^{1 *}$, Mohd Erfy Ismail ${ }^{1}$, Irwan Mahazir Ismail $^{2}$, Rashidah Rahamat ${ }^{3}$, Mohd Fairuz Marian', Nur Faizah Md Amir ${ }^{1}$}

${ }^{1}$ Faculty of Technical \& Vocational Education,

Universiti Tun Hussein Onn Malaysia, 86400 Parit Raja, Batu Pahat, Johor, MALAYSIA

${ }^{2}$ Centre for Instructional Technology \& Multimedia,

Universiti Sains Malaysia, Penang, MALAYSIA

${ }^{3}$ English Language Teaching Centre, Ministry of Education

*Corresponding Author

DOI: https://doi.org/10.30880/ojtp.2021.06.01.006

Received 25 January 2021; Accepted 20 March 2020; Available online 31 March 2021

\begin{abstract}
The technological and telecommunication development of this decade has had a profound impact, especially on the education system. In relation to this development, mobile technology in learning or M-learning is a new concept in the learning process. Examples of portable technology include PDAs (Personal Digital Assistants), Smartphones, iPads, Tablets, and more. Thus, the availability of these advanced technologies promotes an environment of m-learning among students as it is easy to carry, lightweight, and not burdensome. Through the applications of Google, Facebook, YouTube, Edmodo, Twitter, WhatsApp, and Instagram, information is available anytime and anywhere and to anyone. The objectives of this study were to identify the level of students' knowledge of m-learning, identify students' perceptions of m-learning, identify the applicability of students' application to m-learning and identify the relationship between students' level of knowledge and applications usage of m-learning. This questionnaire was used in the data generation, which was analyzed descriptively by using statistical Package for the Social Version 20 (SPSS Statistic 20). The respondents of this study were 204 students in the first year of Faculty Technical and Vocational Education. The finding of the study showed that the use of $\mathrm{m}$ learning in the teaching and learning process has a positive impact which had a min value of 4.00 and above. Besides, this study showed that the use of m-learning is highly recommended as it provides a more engaging learning experience for students. Researchers have suggested that its use of m-learning includes urban and rural students in line with the government's goal of developing an innovative and competitive convergence-based generation.
\end{abstract}

Keywords: M-learning, teaching and learning, student performance

\section{Introduction}

Teachers in the 21 st century need to improve the quality of teaching and learning by diversifying methods and tools that can help activities in the classroom (Alismail \& McGuire, 2015). This includes the use of tools that are appropriate to the latest technological developments in learning, where it helps students to clearly understand the content of the lesson, programs taught, and actively interact with teachers and other fellow students either individually or in groups ( $\mathrm{Su}$ et al., 2005). 21st-century teacher education programs focus more on exposure to the use of new technologies for classroom teaching purposes (Amiruddin et al., 2020). This is because the ability of teachers in integrating the latest technology in teaching and learning can influence the effectiveness of lesson delivery as well as 
solve problems that arise in the classroom (Katitia, 2015; Ismail et al., 2017). Teachers should have the ability to integrate technology to reveal the content of the lesson to students. This is in line with the concept of technology for educational purposes that facilitate teachers in improving students' knowledge and skills with technology (Ertmer \& Ottenbreit-Leftwich, 2010; Sumarwati et al., 2020). Teachers have a responsibility to impart knowledge and skills through education to the public.

The development of the education system in Malaysia has changed from traditional to online learning methods. Mlearning in educational technology help to find information in the learning process and useful reference at a time must be in line with the changing times of the Industrial Revolution 4.0 (Hari, Darmanto \& Yanggah, (2016). Examples of portable technology include PDAs (Personal Digital Assistants), Smartphones, iPads, Tablets, and more. Thus, the availability of these advanced technologies promotes an environment of m-learning among students as it is easy to carry, lightweight, and not burdensome. Through the applications of Google, Facebook, Youtube, Edmodo, Twitter, Whatsapp, and Instagram, information is available anytime and anywhere and to anyone. Therefore, to be applied in the learning process, students need to take the opportunity to use a variety of mobile applications that are easily accessible and accessible (Hamdan et al., 2012). Chen (2014) conducted a study using online learning at a university in Taiwan to show that the use of technology in language learning is accepted by students. Therefore, m-learning has a positive impact on their self-learning. However, the main issue in this study was the constraints faced by the lecturers where there were lecturers who did not want to try to improve the level of technology during the study, especially for advanced lecturers.

A study by Nawi et al. (2014) found that teachers and students are very satisfied with mobile applications. The use of m-learning can increase motivation among students. This is because m-learning has a creative and innovative value. In Malaysia, the problem arises when teaching and learning are not compatible with classroom activities or there are technological facilities that do not function as intended to meet the teaching and learning needs. Some teachers are not good at using technology today for teaching especially for older teachers. They also find the use of Information and Communication Technology (ICT) increasingly sophisticated and difficult to learn. There are various weaknesses of teachers in delivering learning content, but can be improved by using new technology (Carrington, 2016) to attract students by using various technology applications. The objectives of this study were to identify the level of students' knowledge of m-learning, identify students' perceptions of m-learning, identify the applicability of students' application to m-learning and identify the relationship between students' level of knowledge and applications usage of m-learning.

\section{Methodology}

This study used the design of a type of survey, which is through a quantitative approach. Questionnaires were distributed to the study sample face to face.

\section{Respondents}

The study population is Bachelor of Technical and Vocational Education (UTHM) students, especially 1st Year students with simple random sampling techniques. A total of 204 students answered the study instrument. The total number of students taking the course is 310 . Therefore, a total of 204 students involved in this study met the same number of samples as presented by Krejcie and Morgan (1970).

\section{Instrument}

Data were collected using modified questionnaires based on previous studies. The modified questionnaire was subsequently obtained by the expert before use in the study. The questionnaire was first tested by conducting a pilot study involving 30 students. Students involved in this pilot study have similar characteristics to the actual study participants. The questionnaire contains 4 sections, sections A, B, C, and D. Section A contains respondents' background such as gender, age, and specialization in FPTV UTHM, section B contains items about Student Knowledge level in m-learning, section $\mathrm{C}$ contains items about student perceptions of m-learning and section $\mathrm{D}$ contain items about students' use of m-learning. Each item uses a five-level Likert scale of strongly disagree, disagree, strongly disagree, agree, and strongly agree.

\section{Data Analysis}

Data were collected and analyzed using SPSS Statistic version 20. Based on the pilot study, Cronbach's alpha test was performed and the value obtained was 0.961 . This value is in a good category. According to Chua (2011), the alpha value of the questionnaire exceeding 0.70 is high reliability. The analysis used in this study involves descriptive and inference analysis. Descriptive analysis is intended to describe or describe something. It used indicators such as mean, standard deviation, median, mode, and normal distribution (Chua, 2011). It is intended to facilitate the updating of data to make data decisions faster and faster. While inference analysis will see if there is a relationship between the variables studied. In this study, study questions one, two, and three used descriptive analysis. Inference analysis was performed to answer the fourth study question.

\section{Finding}


Descriptive findings of related variables are reported at the level early. Descriptive analysis of the mean value of the set of items contained in the form questionnaires was conducted for the first, second, and third research questions. Pearson analysis was then performed to answer the fourth study question. To find out the mean value of each variable researched, the researchers quantified and interpreted the mean scores into five stages as shown in Table 1.

Table 1 - Interpretation of 5-level average scores (likert scale 5)

\begin{tabular}{cc}
\hline Likert Scale & Interpretation \\
\hline 1 & Strongly Disagree \\
2 & Disagree \\
3 & Less Disagree \\
4 & Agree \\
5 & Strongly Agree \\
\hline
\end{tabular}

The results of this study are described and discussed based on objectives no 1, 2, and 3 of the study as follows:

Table 2 - Analysis of student's knowledge level in use of M-learning

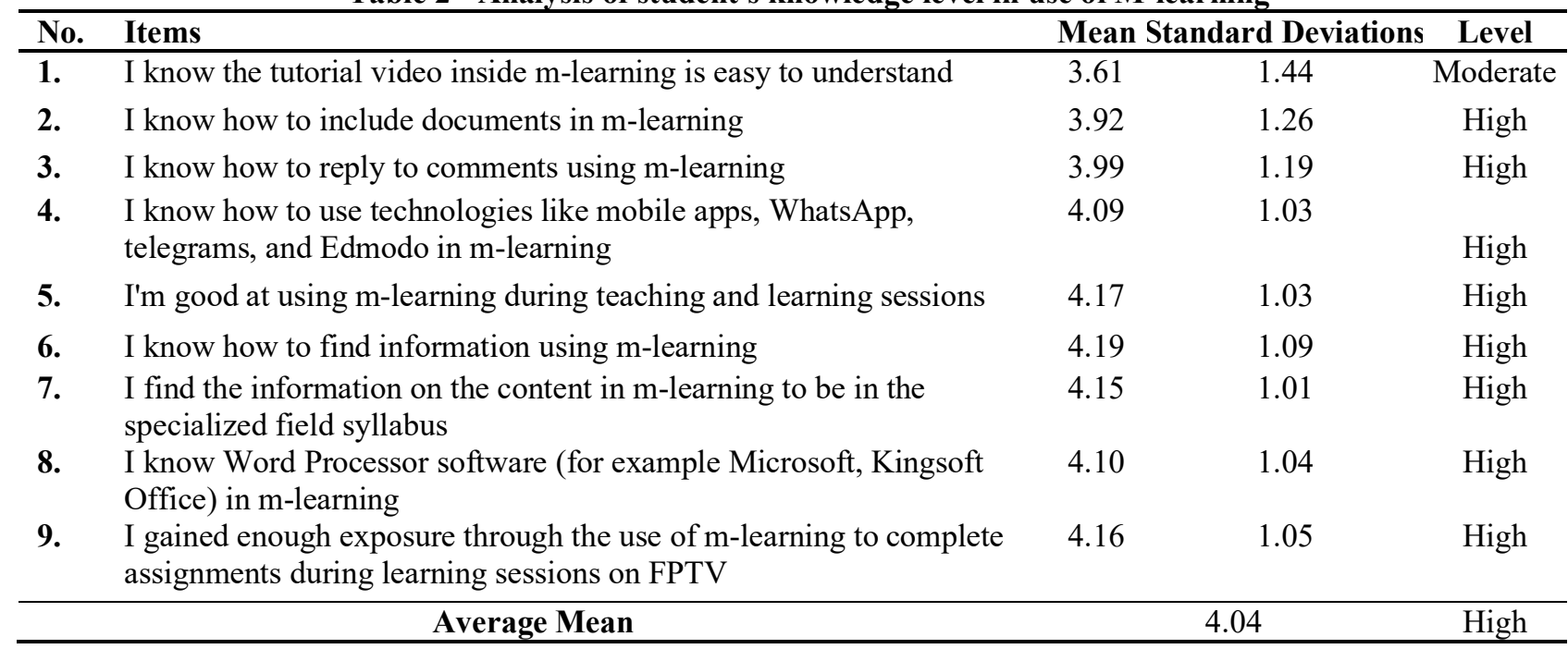

Table 2 shows that the overall average level of students' knowledge of m-learning is high with a 4.04 rating. For item level knowledge students show a high level of assessment with 4.19 students are skilled in finding information using m-learning and students gain sufficient exposure through the use of m-learning to complete assignments during learning sessions on FPTV. However, the analysis also shows the lowest mean of the first item I know the video tutorial in m-learning is easy to understand with the mean value of 3.61. This clearly shows that only a few students understand video tutorials in m-learning.

Table 3 - Analysis of student perceptions of use of M-learning

\begin{tabular}{|c|c|c|c|c|}
\hline No. & Items & Mean & Standard Deviations & Level \\
\hline 1. & Learning is easier to understand using mobile applications & 3.97 & 1.31 & High \\
\hline 2. & $\begin{array}{l}\text { I can easily upload assignments provided by lecturers through the use of } \\
\text { m-learning }\end{array}$ & 4.07 & 1.18 & High \\
\hline 3. & $\begin{array}{l}\text { I can easily access mobile technology applications without time } \\
\text { constraints }\end{array}$ & 4.13 & 1.09 & High \\
\hline 4. & $\begin{array}{l}\text { I can easily access mobile technology applications without space } \\
\text { constraints }\end{array}$ & 4.09 & 1.06 & High \\
\hline 5. & I can easily use the mobile application for reference & 4.03 & 1.10 & High \\
\hline 6. & I can get information quickly through the use of m-learning & 3.95 & 1.24 & High \\
\hline 7. & Learning to use technology is more time-saving & 4.12 & 1.08 & High \\
\hline 8. & Mobile technology tools can improve my learning performance & 4.11 & 1.06 & High \\
\hline 9. & I think using m-learning is an effective interactive learning & 4.12 & 1.07 & High \\
\hline & Average Mean & \multicolumn{2}{|r|}{4.07} & High \\
\hline
\end{tabular}


Table 3 shows the analysis results of students' perceptions of the use of m-learning in teaching and learning as a whole with a mean of 4.07. Through item analysis all respondents agreed that the use of m-learning was very helpful to students. For student perceptions items showed a high rating of 4.13 which means I can easily access mobile technology applications without time constraints. This means that students can search for information at any time.

Table 4 - Analysis of application usability by students against the use of M-learning

\begin{tabular}{|c|c|c|c|c|}
\hline No. & Items & Mean & Standard Deviations & Level \\
\hline 1. & I enjoy using m-learning because it is user friendly & 3.97 & 1.28 & High \\
\hline 2. & I can easily download learning materials from the m-learning application & 4.00 & 1.11 & High \\
\hline 3. & I can pick any sub topic at any time & 4.14 & 1.92 & High \\
\hline 4. & M-learning applications can be used without the help of others & 4.08 & 1.04 & High \\
\hline 5. & User guides are easy to follow & 4.03 & 1.11 & High \\
\hline 6. & $\begin{array}{l}\text { The use of mobile technology helped me to understand a topic of m- } \\
\text { learning }\end{array}$ & 4.02 & 1.16 & High \\
\hline 7. & $\begin{array}{l}\text { The search for information using mobile technology facilitates m-learning } \\
\text { learning activities }\end{array}$ & 4.10 & 1.11 & High \\
\hline 8. & $\begin{array}{l}\text { The use of m-learning has made it easy for me to learn anytime and } \\
\text { anywhere }\end{array}$ & 4.11 & 1.05 & High \\
\hline 9. & I can easily understand the subject by using m-learning & 3.97 & 1.23 & High \\
\hline & Average Mean & \multicolumn{2}{|r|}{4.05} & High \\
\hline
\end{tabular}

Based on Table 4 the overall level of applicability of students to the use of m-learning in teaching and learning is at a high level of 4.05. The average respondent has a positive acceptance of the usefulness of the m-learning application. Respondents strongly believe that m-learning has the potential to improve the quality of academic achievement since the mean value of this item is 4.14 . This clearly shows that students can choose any of the sub-topics at any time because activities are easy to do, activities are effective, activities are productive, activities can be done as desired and activities can be done immediately.

The fourth objective of this study was to identify the relationship between the level of knowledge and applicability of students to the use of m-learning. The results of the correlation analysis are shown in Table 5.

Table 5 - Correlation between students' level of knowledge and applicability of m-learning

\begin{tabular}{llll}
\hline & & Knowledge Level & Application usability \\
\hline Knowledge Level & Correlation & 1 & $0.744^{* *}$ \\
& $\begin{array}{l}\text { Pearson } \\
\text { Sig. (2-tailed) }\end{array}$ & & 0.000 \\
& $\mathrm{~N}$ & 204 & 204 \\
\hline Application usability & Correlation & $0.744^{* *}$ & 1 \\
& $\begin{array}{l}\text { Pearson } \\
\text { Sig. (2-tailed) }\end{array}$ & 0.000 & \\
& $\mathrm{~N}$ & 204 & 204 \\
\hline
\end{tabular}

The results show based on table 5 the level of knowledge and applicability of students is at a very high level. Significant value at $r=0.744$. This clearly shows that if students have high levels of knowledge, then the usefulness of m-learning applications is high. Besides, it facilitates learning sessions and students can move quickly if they know using the m-learning system to download notes and so on. Also, the use of m-learning in teaching and learning can enhance the effectiveness of learning.

\section{Discussion}

Based on the findings show that respondents are knowledgeable in the use of m-learning. This is because the level of student knowledge of m-learning is at a high level (4.04). Several efforts need to be made by teachers to meet the demands of 21st-century education (Bickham et al., 2008), that teachers should be prepared to add knowledge and skills related to the latest ICT technology that can facilitate the teaching and learning process, teachers need to undergo training on educational technology to improve the quality of self, teachers need to have accurate time planning and teachers should always improve their skills in using various methods as well as new technologies that can improve the quality of teaching in the classroom. Meanwhile, the findings show that students' perceptions of m-learning are at a high level. This is because, the overall mean score for perceptions is high at 4.07. Rinkevich (2011) suggests that teachers need to be creative and have the ability to increase students 'interest to explore a variety of knowledge 
throughout the learning process. Lastly, the overall usability of the application is high with a mean score of 4.05 . This indicates that respondents are interested in m-learning as various applications have been specially designed to enable users to create short documents, entertainment programs, file management and more. Also, students can easily use the app without the help of others because it is easy to follow user-friendly and user-friendly.

Moreover, respondents also found that they could easily use a mobile application to make referrals. This is because, learning does not have to happen only in the classroom or in the lecture hall but the learning process can take place anywhere. Respondents believe that $\mathrm{m}$-learning can improve learning performance. M-learning methods are more effective than traditional methods. Therefore, students think learning traditional methods will not help them increase their interest and mastery of any subject. This is supported by Zakiah et. al (2013) stating that traditional teaching methods result in one-way learning, poor interaction, and lack of learning resources. M-learning refers to learning using wireless equipment that can be implemented anytime and anywhere (Siraj \& Kumaran, 2006). Based on the findings of the research on the level of knowledge and application usefulness, the Pearson correlation coefficient is high. This demonstrates the extent to which students' knowledge affects usage m-learning. According to Shuib (2010) noted that user differences need to be taken into account by application developers during the development process. This is because, each application developed depends on the target group that will use the application.

Therefore, in this study the differences between male and female students in the use of m-learning were studied by the researcher. The difference was $53.9 \%$ for male students while female students were $46.1 \%$. This is because, boys are more interested in using this mobile app than girls. This indicates that the percentage of male students is higher than that of female students. This is because, male students are more attentive to the material they need, especially when discussing lectures with lecturers in a lecture session conducted than female students. Male students are likely more likely to adopt the new millennial learning approach by using m-learning facilities to access the materials needed during the lecture in the lecture hall than the female students are more inclined to the traditional learning approach. Therefore, traditional learning requires students to copy notes provided by the lecturer and students can ask the lecturer directly if they do not understand a lesson. However, with the student's m-learning system it is difficult to ask unanswered questions and it may take a long time to meet in the next class (Hamdan et al., 2012). In a nutshell, the evolution of information technology and the sophistication of application knowledge has changed the pattern of education and the delivery of knowledge in line with the call of the Ministry of Higher Education.

\section{Conclusion}

The technological and telecommunications developments of this decade have had a profound impact, especially on the education system. Therefore, mobile technology in learning or m-learning is a new concept in the learning process. The findings can be concluded that students' level of knowledge about m-learning, students' perception of m-learning and students' use of m-learning are high. This indicates that students in the Faculty of Technical and Vocational Education, UTHM can embrace the use of m-learning in the modern education world as it enables students to act quickly to find materials and interact with peers in a short time. Besides, students will become more interactive with the latest software assisted with the use of the latest gadgets. Indirectly, self-directed learning will take place. Students will interact to explore, analyze, try and find critically, creatively and innovative solutions to their assigned tasks. It is needed to consider these recommendations to carry out more effective and efficient studies in this field. Experimental studies might be considered more useful. It might be more useful to apply mobile learning applications with face to face training. The results obtained from the studies should be supported with theoretical foundations in the literature. Therefore, should conduct studies in other fields to compare the level of acceptance of m-learning among students. Thus, it is not immediately possible to see whether there is any similarity in the use of applications by students to the use of m-learning. Next, carry out more detailed tests for students by developing strategic supervision plans that reflect the education and mission of the university. Lastly, carry out a more detailed study by identifying the asbestos or constraints affecting the use of m-learning among faculty and students at UTHM.

\section{Acknowledgement} K011.

The authors would like to thank the Ministry of Education Malaysia for supporting this research through PPG VOT

\section{References}

Alismail, H. A. \& McGuire, P. (2015). 21st Century Standards and Curriculum: Current Research and Practice. Journal of Education and Practice, 6 (6):150-154

Amiruddin, M. H., Ismail, I. M., Razali, N., Ismail, M. E., Noriyani Doman, Noorazman Abd. Samad, Azwin Arif Abdul Rahim. (2020). The Motivation Level towards the Application of Google Apps among Part-time Students: A Case Study. Journal of Technical Education and Training, 12 (1): 254-260

Bickham, M., Bradburn, F., Edwards, R., Fallon, J., Luke, J., Mossman, D. \& Ness, L. A. V. (2008). Learning in the 21st Century: Teaching Today's Students on Their Terms. International Education Advisory Board. Certiport 
Su, B., Bonk, C. J., Magjuka, R. J., Liu, X.J.. \& Lee, S.H. (2005). The Importance of Interaction in Web-Based Education: A Program-level Case Study of Online MBA Courses. Journal of Interactive Online Learning, 4 (1): 1-19

Chen, Y. L. (2014). A Study on Student Selfefficacy and Technology Acceptance Model within an Online Taskbased Learning Environment. Journal of Computers, 2014, 9 (1): 34-43

Chua, Y. P. (2011). Kaedah dan statistik penyelidikan: Kaedah penyelidikan. Mcgraw-Hill Education

Ertmer, P. A. \& Ottenbreit-Leftwich, A. T. (2010). Teacher Technology Change: How Knowledge, Confidence, Beliefs, and Culture Intersect. Journal of Research on Technology in Education, 42 (3): 255-284

Hamdan, A., Din, R. \& Abdul Manaf, S. Z. (2012). Penerimaan M-Pembelajaran dalam Sistem Pendidikan di Malaysia: Satu Analisis Literatur. UKM, Malaysia 1st International Conference on Mobil Learning, Applications, and services (mobilcase2012)

Hari, Y., Darmanto, D. \& Yanggah, M. E. (2016). Tingkat Adopsi Inovasi Teknologi Sistem M-Learning Dalam Pembelajaran Bahasa Mandarin Pada Tingkat SMA. Proceeding SENDI_U 2016

Ismail, M. E., Ismail, I. M., Othman, H., Amiruddin, M.H., Ariffin, A. (2017). The use of animation video in teaching to enhance the imagination and visualization of student in engineering drawing. IOP Conference Series: Materials Science and Engineering, 203 (1): 012-023

Johanson, G.A. \& Brooks, G.P. (2010). Initial scale development: sample size for pilot studies. Educational and Psychological Measurement ,70(3), 394-400

Katitia, D. M. O. (2015). Teacher Education Preparation program for the 21 st Century. Which way forward for Kenya? Journal of Education and Practice, 6 (24), 57-64

Nawi, A., Hamzah, M. I. \& Abd Sattai, S. A. (2014). Potential Use of Mobile Apps in Islamic Education. The Online Journal of Islamic Education. 2 (2), 26-35

Rinkevich, J. L. (2011) Creative Teaching: Why it Matters and Where to Begin, Journal of Educational Strategies, Issues and Ideas, 84:5, 219-223

Rogers, T. (2003). Mobile Technologies for Informal Learning: paper presented in European Workshop on Mobile and Contextual Learning. Birmingham, UK

Shuib, A. S. (2010). M-Learning Secondary School Curriculum Design: Delphi Techniques. Proceedings of Regional Conference on Knowledge Integration in Information and Communication Technology, 652-665

Siraj, S. \& Kumaran, V. (2006). M-Learning Module Design for Futuristic Secondary School Curriculum Implementation in Malaysia. Kertas Prosiding Konvensyen Teknologi Pendidikan Ke-19, Langkawi

Sumarwati, S., Fitriyani, H., Setiaji, F. M. A., Amiruddin, M. H. \& Jalil, S. A. (2020). Developing Mathematics Learning Media Based on Elearning Using Moodle on Geometry Subject to Improve Students' Higher Order Thinking Skills, International Journal: Interactive Mobile Technologies, 14(4), 182-191

Venkatesh, V., Thong, J. Y. L. \& Xu, X. (2012). Consumer Acceptance and Use of Information Technology: Extending the Unified Theory, MIS Quarterly, 36(1), 157-178

Wahab, N. H. (2011), Faktor-Faktor Yang Mempengaruhi Penggunaan Portal E-Pembelajaran Dalam Kalangan Pelajar Dan Pensyarah Rangkaian Universiti Teknikal Malaysia (MTUN), Thesis Sarjana Pendidikan Teknik dan Vokasional, UTHM)

Zaharah, Saedah, Ghazali \& Nur Hasbuna. (2015). Kajian Model Blended Learning Dalam Jurnal Terpilih: Satu Analisa Kandungan. Jurnal Kurikulum \& Pengajaran Asia Pasifik, 3

Zakiah M. A., Azlina, M. K., \& Yeo, K. J. (2013). Keberkesanan Modul Belajar Melalui Bermain Terhadap Kefahaman Pengalaman Pranombor Kanak-kanak Prasekolah. 2nd International Seminar on Quality and Affordable Education (ISQAE 2013), 305-31 